\title{
COMPARATIVE STUDY OF INGUINAL HERNIA REPAIR BY LICHTENSTEIN METHOD V/S OPEN PRE- PERITONEAL MESH REPAIR- A PROSPECTIVE STUDY
}

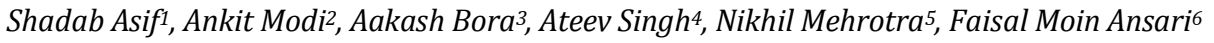 \\ ${ }^{1}$ Assistant Professor, Department of General Surgery, Era's Lucknow Medical College \& Hospital, Lucknow. \\ 2Junior Resident, Department of General Surgery, Era's Lucknow Medical College \& Hospital, Lucknow. \\ 3 Junior Resident, Department of General Surgery, Era's Lucknow Medical College \& Hospital, Lucknow. \\ 4Junior Resident, Department of General Surgery, Era's Lucknow Medical College \& Hospital, Lucknow. \\ 5Junior Resident, Department of General Surgery, Era's Lucknow Medical College \& Hospital, Lucknow. \\ 6Junior Resident, Department of General Surgery, Era's Lucknow Medical College \& Hospital, Lucknow.
}

ABSTRACT
BACKGROUND
Inguinal hernias constitute an important public health problem and often pose a surgical dilemma even for the most skilled
surgeon. ${ }^{1}$ They are the most common form of abdominal wall hernias. The present prospective study was proposed to compare
inguinal hernia repair by Lichtenstein method Vs. Open pre-peritoneal mesh repair regarding drawbacks such as complications,
early recurrence and benefits like lower severity of pain and time of hospital stay/surgery.

\section{MATERIALS AND METHODS}

The present study was a prospective randomised study in the Department of General Surgery at Era's Lucknow Medical College and Hospital from October, 2013. All the patients were followed up for 6 months. Out of 100 patients, 50 underwent Lichtenstein procedure and other 50 underwent open pre-peritoneal mesh repair.

\section{RESULTS}

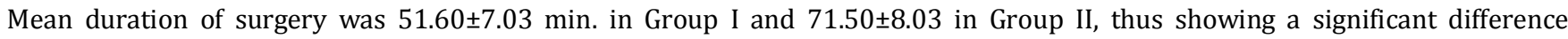
between two groups $(p<0.001)$. Mean duration of hospital stay was $6.72 \pm 0.83$ days in Group I and 5.52 \pm 1.04 days in Group II.

\section{CONCLUSION}

The findings of present study suggested that post-operative complications, pain and recurrence rates were lower in pre-peritoneal repair group as compared to Lichtenstein repair group, hence open pre-peritoneal hernia repair is recommended as a surgical procedure of choice.

\section{KEYWORDS}

Hernia, Pre-peritoneal, Lichtenstein, Hernioplasties.

HOW TO CITE THIS ARTICLE: Asif S, Modi A, Bora A, et al. Comparative study of inguinal hernia repair by Lichtenstein method v/s open pre-peritoneal mesh repair- A prospective study. J. Evolution Med. Dent. Sci. 2017;6(16):1293-1299, DOI: $10.14260 / \mathrm{Jemds} / 2017 / 280$

\section{BACKGROUND}

The subject of repair of inguinal hernia has been full of controversy ever since Eduardo Bassini of Padua University described his method of repair in the manuscript 'Radical Cure of Inguinal Hernias' way back in 1887.

Nyhus and Stoppa developed the concept of preperitoneal repair of inguinal hernia in an effort to reduce the high recurrence rates associated with the anterior repairs popular around that time- most of which in fact were tissue, as against, prosthetic repairs. Around the same time, Lichtenstein ${ }^{2}$ and others started performing anterior tensionfree mesh repairs, also in an attempt to reduce the recurrence rate, postoperative pain and long convalescence associated with traditionally performed Bassini, Shouldice and McVay repairs. Ironically, Lichtenstein's concept of tension-free

Financial or Other, Competing Interest: None.

Submission 18-01-2017, Peer Review 08-02-2017,

Acceptance 17-02-2017, Published 23-02-2017.

Corresponding Author:

Dr. Shadab Asif,

\#592K/34, Subhami Khera,

Telebagh, Lucknow-226002.

E-mail: drshadab.asif@rediffmail.com

DOI: $10.14260 /$ jemds/2017/280 repair by routine implantation of a mesh, which was scathingly criticised as late as 1990,3 is today considered the 'gold standard' in the open treatment of groin hernias.

Approximately 20 million groin hernioplasties are performed each year worldwide, over 17000 operations in Sweden, over 12000 in Finland, over 80000 in England and over 800000 in the USA $4,5,6,7$ Recurrence of inguinal hernia was initially a significant problem; however, with the advent of the tension-free mesh repair as described as Lichtenstein repair (LR), ${ }^{8}$ recurrence rate has consistently been reported as low as $1-4 \%, 9,10,11,12,13$ a drop from up to $50-60 \%$.

Some of the common methods of choice for inguinal hernia repair include (Rehman et al 2010):14

1. Lytle repair.

2. Bassini repair.

3. Shouldice repair.

4. Darn repair (Moloney's).

5. Lichtenstein repair (Mesh repair).

6. Stoppa's repair.

7. Laparoscopic extraperitoneal and intraperitoneal mesh hernioplasty.

In the recent years, the polypropylene mesh has been extensively used with encouraging results. During 1980s, modern herniologists like Lichtenstein and Gilbert simply laid 
a swatch of mesh without sutures deep to or in front of fascia transversalis with good results (Legutko et al., 2008; Yaghoobi et al., 2007; Deysine, 2008). ${ }^{15,16,17}$

Recently the Health Services Research Unit, Institute of Applied Health Sciences, University of Aberdeen, carried out an extensive review of literature to address whether laparoscopic methods were more effective and cost-effective than open mesh methods of inguinal hernia repair. 18

Bhandarkar et al (2006) ${ }^{19}$ in a meta-analysis study of 14 studies concluded that the laparoscopic repair was costlier than open mesh in all but 2 studies. In the review for the management of unilateral hernias, the open flat mesh was considered the least costly option, but provided less quality adjusted life years than TEP or TAPP. TEP was preferred over TAPP as TEP was found to be less costly and more effective. For management of symptomatic bilateral hernias, laparoscopic repair was considered to be more cost-effective as the operation time was reduced and differences in convalescence time are more marked for laparoscopic compared with open mesh repair. The study also addressed the issue of training costs. If the surgeon were to adopt costcontainment strategies such as use of reusable laparoscopic instruments (which is more or less the norm in India) as against disposable ones, use of indigenous balloons devices rather than commercially available ones, sparing use of fixation devices and reliance on sutures for fixation of the mesh, the cost of the laparoscopic hernia repair should be comparable to the open repair. It is likely that many surgeons are already practising these strategies and passing on the benefits of laparoscopic repair to their patients. They suggested that high-volume centers in India undertake prospective studies to carefully document and analyse data related to the cost-effectiveness of laparoscopic hernia repair.

Therefore, the present prospective study was proposed to compare inguinal hernia repair by Lichtenstein method Vs. Open pre-peritoneal mesh repair regarding drawbacks such as complications, early recurrence and benefits like lower severity of pain and time of hospital stay/surgery.

\section{Aim and Objectives}

1. To study the benefits and drawbacks of hernial repair by Lichtenstein method and open peritoneal mesh repair.

2. To study and compare the intra-operative and postoperative findings of Lichtenstein method and open peritoneal mesh repair of hernia.

\section{MATERIALS AND METHODS}

The present study was a prospective randomised study in the Department of General Surgery at Era's Lucknow Medical College and Hospital from October, 2013. All the patients were followed up from the time of admission till six months from the day of surgery at monthly intervals.

\section{Inclusion Criteria}

Patients undergoing elective hernial surgery.

\section{Exclusion Criteria}

Patients undergoing emergency surgeries.

Patient affected with HIV, HCV, HBsAg or Diabetes mellitus.

\section{Duration of Study}

Eighteen months starting from October, 2013.

\section{Sample Size and Randomisation}

A total of 100 patients falling in sampling frame were enrolled in the study. They were randomly allocated to one of the following two groups:

Group I ( $n=50)$ - Patients in this group underwent hernia repair using Lichtenstein procedure.

Group II $(n=50)$ - Patients in this group underwent hernia repair using open pre-peritoneal mesh procedure.

Randomisation was done through computerised random number generation. Both the procedures were performed as per standard guidelines.

\section{Assessment- The following factors were assessed. Operative-}

Duration of Operation.

\section{Intra-Operative}

- Haemorrhage.

- Injury to nerve.

- Urinary bladder injury.

- Others.

\section{Post-Operative Complications}

Immediate (0-7 Days)

- Haematoma.

- Wound infection.

- Urinary retention.

- Numbness in inguinal area.

Early (7-30 Days)

- Wound healing problems/wound gapping.

- Chronic infection/sinus tract.

\section{Late (30 Days and Beyond)}

- Chronic pain.

- Reoccurrence.

- Scrotal swelling/local swelling/testicular swelling.

- Seroma/hydrocoele.

\section{Other Factors}

- Total cost.

- Total duration of hospital stay.

- Returned to work.

\section{Duration of Surgery}

Total duration of surgery was noted.

\section{Chronic Pain}

Chronic pain was assessed by Visual analogue scale (VAS) where pain was graded $0-10$ on the basis of facial expression, where 0 denotes no pain and 10 as worst imaginable pain.

\section{Materials \\ Polypropylene Mesh}

Polypropylene mesh of $6 \times 3$ was used in Lichtenstein method and $6 \times 6$ was used in pre-peritoneal mesh repair.

\section{Sutures}

Prolene 2.0 RB was used for mesh fixation and Vicryl 2.0 RB was used for external aponeurosis.

One dose of antibiotic was given pre-operatively and scrotal support was given in all the patients. Necessary 
laboratory and radiographic investigations were done before planning for operative procedure.

\section{RESULTS}

The present study was conducted in the Department of Surgery, Era's Lucknow Medical College, Lucknow to study the benefits and drawbacks of hernial repair by Lichtenstein method and open pre-peritoneal mesh repair and to compare the intra-operative and post-operative findings of both the operative procedures.

100 patients were randomly administered two different operative procedures as shown below.

\begin{tabular}{|c|c|c|c|c|c|c|c|}
\hline \multirow[t]{2}{*}{ Variables } & \multirow{2}{*}{$\begin{array}{c}\text { Total } \\
\text { Subjects }\end{array}$} & \multicolumn{2}{|c|}{$\begin{array}{l}\text { Group I } \\
(n=50)\end{array}$} & \multicolumn{2}{|c|}{$\begin{array}{c}\text { Group II } \\
(n=50)\end{array}$} & \multicolumn{2}{|c|}{$\begin{array}{c}\text { Statistical } \\
\text { Significance }\end{array}$} \\
\hline & & No. & $\%$ & No. & $\%$ & $\chi^{2}$ & $\mathbf{P}$ \\
\hline Lt. Inguinal Hernia & 25 & 13 & 26.00 & 12 & 24.00 & \multirow{3}{*}{7.233} & \multirow{3}{*}{0.124} \\
\hline Rt. Inguinal Hernia & 57 & 32 & 64.00 & 25 & 50.00 & & \\
\hline B/L Inguinal Hernia & 18 & 5 & 10.00 & 13 & 14.00 & & \\
\hline
\end{tabular}

\begin{tabular}{|c|c|c|c|c|c|c|c|}
\hline \multirow{2}{*}{ Variables } & \multirow{2}{*}{$\begin{array}{c}\text { Total } \\
\text { Subjects }\end{array}$} & \multicolumn{2}{|c|}{ Group I (n=50) } & \multicolumn{2}{|c|}{ Group II $(n=50)$} & \multicolumn{2}{|c|}{ Statistical Significance } \\
\hline & & No. & $\%$ & No. & $\%$ & $\chi^{2}$ & $\mathbf{P}$ \\
\hline \multicolumn{8}{|c|}{ History of Smoking } \\
\hline Positive & 45 & 25 & 50.00 & 20 & 40.00 & \multirow{2}{*}{1.010} & \multirow{2}{*}{0.315} \\
\hline Negative & 55 & 25 & 50.00 & 30 & 60.00 & & \\
\hline \multicolumn{8}{|c|}{ History of Straining } \\
\hline BPH & 6 & 3 & 6.00 & 3 & 6.00 & \multirow{4}{*}{1.831} & \multirow{4}{*}{0.608} \\
\hline Constipation & 9 & 5 & 10.00 & 4 & 8.00 & & \\
\hline Cough & 10 & 3 & 6.00 & 7 & 14.00 & & \\
\hline No Straining & 75 & 39 & 78.00 & 36 & 72.00 & & \\
\hline
\end{tabular}

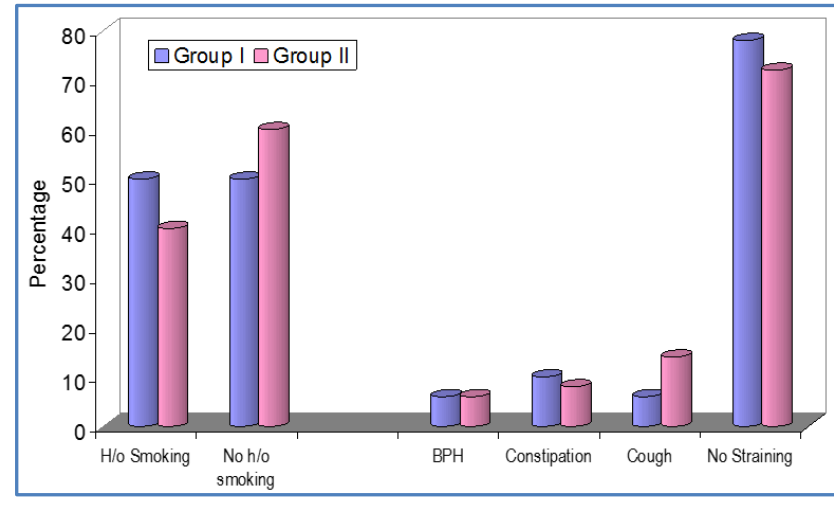

\begin{tabular}{|c|c|c|c|c|c|c|c|}
\hline \multirow[t]{2}{*}{ Variables } & \multirow{2}{*}{$\begin{array}{c}\text { Total } \\
\text { Subjects }\end{array}$} & \multicolumn{2}{|c|}{$\begin{array}{l}\text { Group I } \\
(n=50)\end{array}$} & \multicolumn{2}{|c|}{$\begin{array}{c}\text { Group II } \\
(n=50)\end{array}$} & \multicolumn{2}{|c|}{\begin{tabular}{|c|} 
Statistical \\
Significance
\end{tabular}} \\
\hline & & No. & $\%$ & No. & $\%$ & $\chi^{2}$ & p \\
\hline \multicolumn{8}{|c|}{ Side of Swelling } \\
\hline Bilateral & 16 & 5 & 10.00 & 13 & 26.00 & \multirow{3}{*}{4.352} & \multirow{3}{*}{0.113} \\
\hline Left & 26 & 14 & 28.00 & 12 & 24.00 & & \\
\hline Right & 58 & 31 & 62.00 & 25 & 50.00 & & \\
\hline \multicolumn{8}{|c|}{ Site of Swelling } \\
\hline Bilateral & 16 & 5 & 10.00 & 11 & 22.00 & \multirow{2}{*}{5.361} & \multirow{2}{*}{0.069} \\
\hline Inguinal & 84 & 45 & 90.00 & 39 & 78.00 & & \\
\hline
\end{tabular}

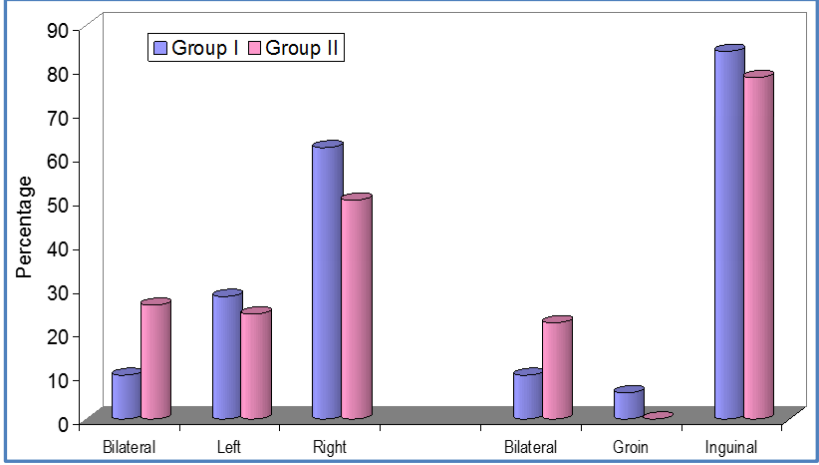

\begin{tabular}{|c|c|c|c|c|c|}
\hline Group & $\begin{array}{c}\text { No. of } \\
\text { Subjects }\end{array}$ & Minimum & Maximum & Mean & S.D. \\
\hline Group I & 50 & 2 & 12 & 6.92 & 2.31 \\
\hline Group II & 50 & 3 & 12 & 6.74 & 2.15 \\
\hline Total & $\mathbf{1 0 0}$ & $\mathbf{2}$ & $\mathbf{1 2}$ & $\mathbf{6 . 8 3}$ & $\mathbf{2 . 2 2}$ \\
\hline \multicolumn{5}{|c|}{$\begin{array}{c}\text { Table 4. Between Group Comparison } \\
\text { of Duration of Swelling (Months) }\end{array}$} \\
\hline
\end{tabular}

't'=0.404; $\mathrm{p}=0.687$

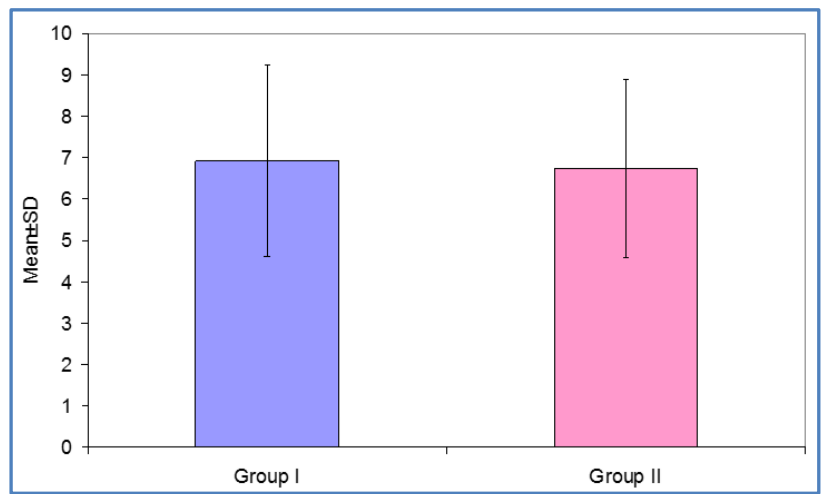




\begin{tabular}{|c|c|c|c|c|c|}
\hline Group & $\begin{array}{c}\text { No. of } \\
\text { Subjects }\end{array}$ & Minimum & Maximum & Mean & S.D. \\
\hline Group I & 50 & 45 & 75 & 51.60 & 7.03 \\
\hline Group II & 50 & 50 & 90 & 71.50 & 8.03 \\
\hline Total & $\mathbf{1 0 0}$ & $\mathbf{4 5}$ & $\mathbf{9 0}$ & $\mathbf{6 1 . 5 5}$ & $\mathbf{1 2 . 5 1}$ \\
\hline \multicolumn{6}{|c|}{$\begin{array}{c}\text { Table 5. Between Group Comparison } \\
\text { of Duration of Surgery (Minutes) }\end{array}$} \\
\hline
\end{tabular}

't'=13.181; $\mathrm{p}<0.001$ (Significant)

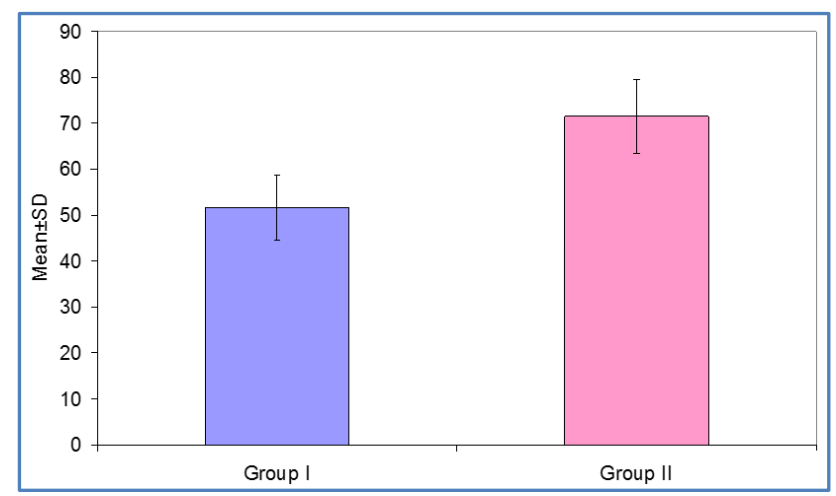

\begin{tabular}{|c|c|c|c|c|c|c|c|}
\hline \multirow{2}{*}{ Variables } & \multirow{2}{*}{ Total Subjects } & \multicolumn{2}{|c|}{ Group I (n=50) } & \multicolumn{2}{c|}{ Group II (n=50) } & \multicolumn{2}{c|}{ Statistical Significance } \\
\cline { 3 - 8 } & & No. & $\mathbf{0}$ & No. & $\mathbf{\%}$ & $\chi^{\mathbf{2}}$ & $\mathbf{P}$ \\
\hline Urinary Retention & 18 & 12 & 24.00 & 6 & 12.00 & 2.439 & 0.112 \\
\hline Wound Infection & 10 & 7 & 14.00 & 3 & 6.00 & 1.778 & 0.182 \\
\hline Haemorrhage & 8 & 1 & 2.00 & 7 & 14.00 & 4.891 & $\mathbf{0 . 0 1 2}$ \\
\hline Injury to Nerve & 1 & 1 & 2.00 & 0 & 0.00 & 1.010 & 0.315 \\
\hline Bladder Injury & 1 & 0 & 0.00 & 1 & 2.00 & 1.010 & 0.315 \\
\hline & Table 6. Between Group Comparison of Complications during Surgery and Post-operative Complications (Immediate) \\
\hline
\end{tabular}

*Significant

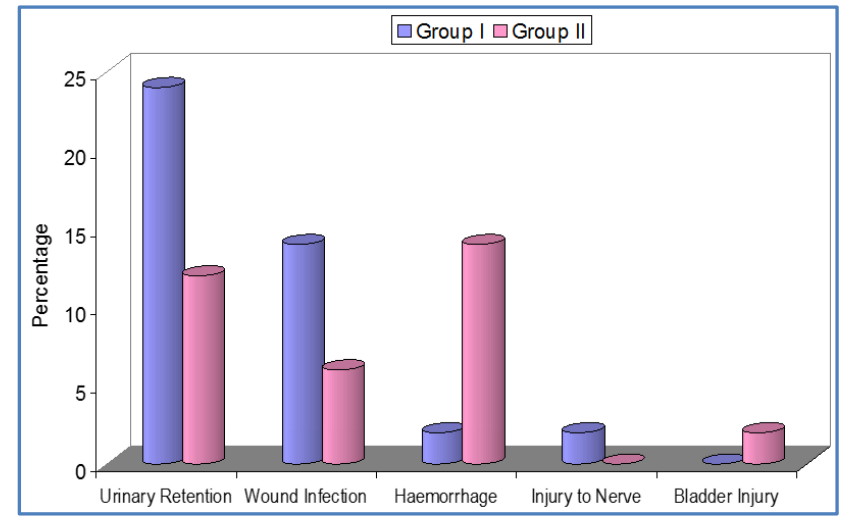

\begin{tabular}{|c|c|c|c|c|c|c|}
\hline Group & $\begin{array}{c}\text { No. of } \\
\text { Subjects }\end{array}$ & Min & Max & Mean & S.D. & Median \\
\hline Group I & 50 & 4 & 8 & 6.56 & 0.88 & 7 \\
\hline Group II & 50 & 3 & 7 & 5.44 & 1.01 & 6 \\
\hline Total & $\mathbf{1 0 0}$ & $\mathbf{3}$ & $\mathbf{8}$ & $\mathbf{6 . 0 0}$ & $\mathbf{1 . 1 0}$ & $\mathbf{6}$ \\
\hline \multicolumn{7}{|c|}{$\begin{array}{c}\text { Table 7. Between Group Comparison } \\
\text { of Pain at 1 }{ }^{\text {st }} \text { week (VAS Score) }\end{array}$}
\end{tabular}

' $\mathrm{z}$ '=5.365; $\mathrm{p}<0.001$ (Mann-Whitney U test) (Significant)

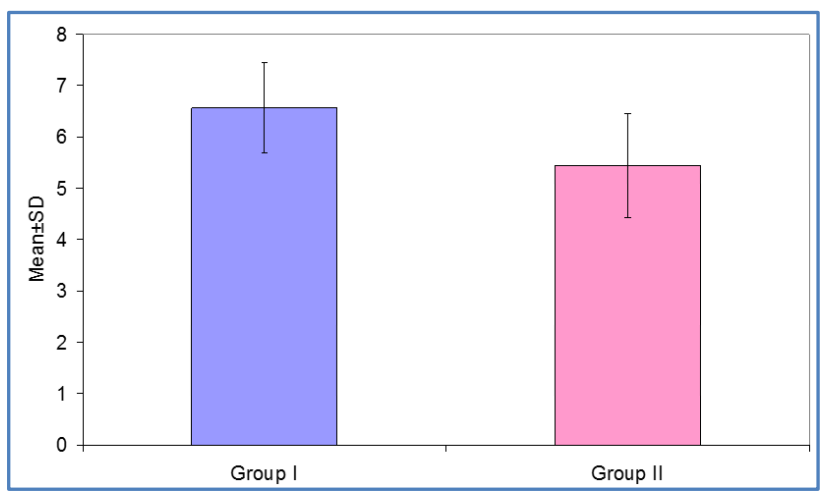

\begin{tabular}{|c|c|c|c|c|c|c|}
\hline Group & $\begin{array}{c}\text { No. of } \\
\text { Subjects }\end{array}$ & Min & Max & Mean & S.D. & Median \\
\hline Group I & 50 & 1 & 4 & 3.16 & 0.71 & 3 \\
\hline Group II & 50 & 1 & 4 & 2.26 & 0.63 & 2 \\
\hline Total & $\mathbf{1 0 0}$ & $\mathbf{1}$ & $\mathbf{4}$ & $\mathbf{2 . 7 1}$ & $\mathbf{0 . 8 1}$ & $\mathbf{3}$ \\
\hline \multicolumn{6}{|c|}{ Table 8. Between Group Comparison } \\
of Chronic Pain at 3 Months (VAS Score) \\
\hline
\end{tabular}

'z'=5.740; $p<0.001$ (Mann-Whitney U test) (Significant)

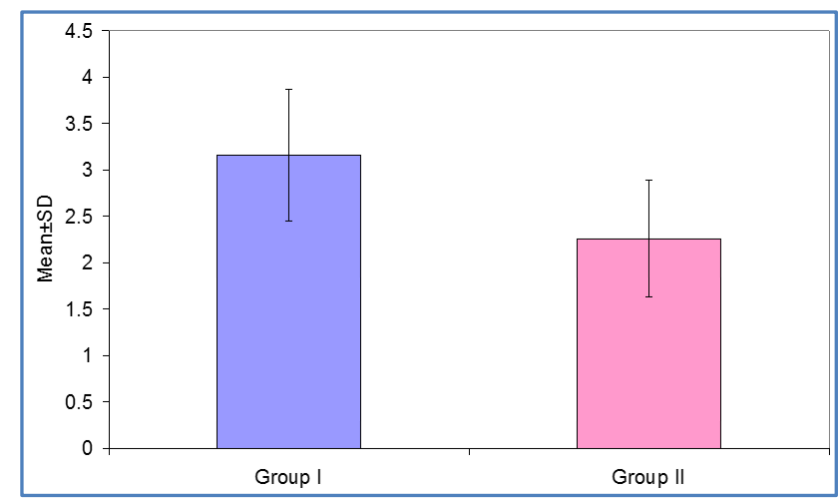

\begin{tabular}{|c|c|c|c|c|c|c|c|}
\hline \multirow{2}{*}{ Variables } & \multirow{2}{*}{$\begin{array}{c}\text { Total } \\
\text { Subjects }\end{array}$} & \multicolumn{2}{|c|}{$\begin{array}{c}\text { Group I } \\
(\mathbf{n = 5 0}\end{array}$} & \multicolumn{2}{c|}{$\begin{array}{c}\text { Group II } \\
(\mathbf{n = 5 0}\end{array}$} & \multicolumn{2}{c|}{$\begin{array}{c}\text { Statistical } \\
\text { Significance }\end{array}$} \\
\cline { 3 - 8 } & & $\mathbf{N o}$ & $\mathbf{\%}$ & $\mathbf{N o}$ & $\mathbf{\%}$ & $\chi^{\mathbf{2}}$ & $\mathbf{P}$ \\
\hline Recurrence & 6 & 6 & 12.00 & 0 & 0.00 & 6.383 & 0.012 \\
\hline $\begin{array}{c}\text { Scrotal } \\
\text { Swelling }\end{array}$ & 4 & 4 & 8.00 & 0 & 0.00 & 4.167 & 0.041 \\
\hline Seroma & 2 & 0 & 0.00 & 2 & 4.00 & 2.041 & 0.153 \\
\hline
\end{tabular}

Table 9. Between Group Comparison of late

Post-operative Complications 30 days and beyond 


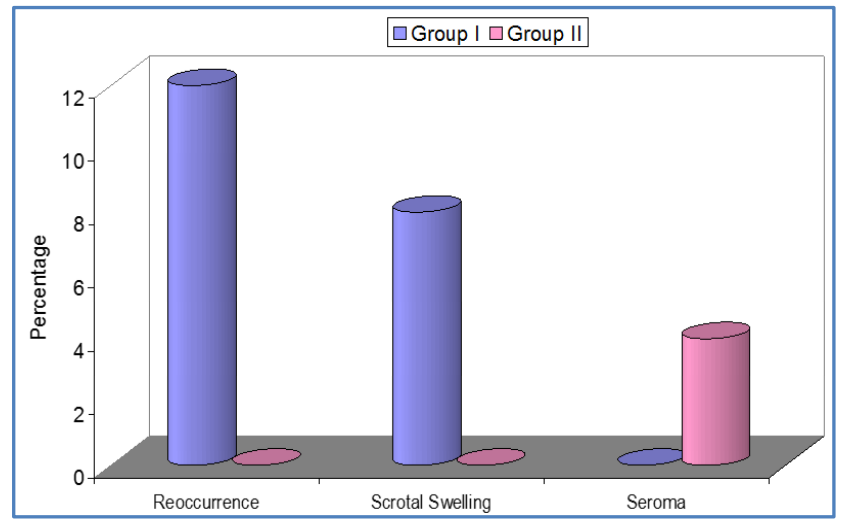

\begin{tabular}{|c|c|c|c|c|c|c|c|}
\hline \multirow{2}{*}{ Variables } & \multirow{2}{*}{$\begin{array}{c}\text { Total } \\
\text { Subjects }\end{array}$} & \multicolumn{2}{|c|}{$\begin{array}{c}\text { Group I } \\
(\mathbf{n}=\mathbf{5 0})\end{array}$} & \multicolumn{2}{c|}{$\begin{array}{c}\text { Group II } \\
\text { (n=50) }\end{array}$} & \multicolumn{2}{c|}{$\begin{array}{c}\text { Statistical } \\
\text { Significance }\end{array}$} \\
\cline { 3 - 8 } & No. & $\%$ & No. & $\%$ & $\chi^{\mathbf{2}}$ & P \\
\hline $\begin{array}{c}\text { No } \\
\text { Drainage }\end{array}$ & 100 & 50 & 100.00 & 50 & 100.00 & - & - \\
\hline $\begin{array}{c}\text { Antibiotic } \\
\text { Use }\end{array}$ & 100 & 50 & 100.00 & 50 & 100.00 & - & - \\
\hline \multicolumn{6}{|c|}{$\begin{array}{c}\text { Table 10. Between Group Comparison } \\
\text { of Drainage and Use of Antibiotics }\end{array}$} \\
\hline
\end{tabular}

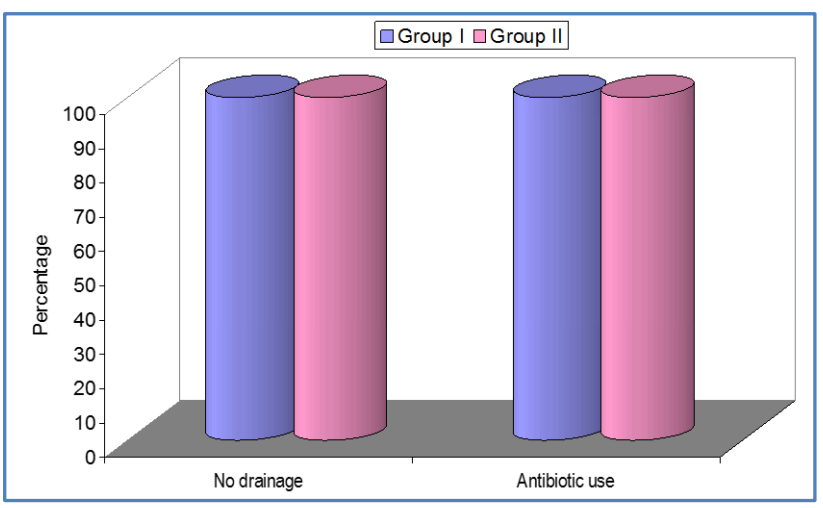

\begin{tabular}{|c|c|c|c|c|c|c|}
\hline Group & $\begin{array}{c}\text { No. of } \\
\text { Subjects }\end{array}$ & Min & Max & Mean & S.D. & Median \\
\hline $\begin{array}{c}\text { Group } \\
\text { I }\end{array}$ & 50 & 7500 & 11000 & 8970.00 & 785.13 & 9000 \\
\hline $\begin{array}{c}\text { Group } \\
\text { II }\end{array}$ & 50 & 9000 & 12000 & 10425.00 & 766.40 & 10500 \\
\hline Total & $\mathbf{1 0 0}$ & $\mathbf{7 5 0 0}$ & $\mathbf{1 2 0 0 0}$ & $\mathbf{9 6 9 7 . 5 0}$ & $\mathbf{1 0 6 3 . 2 1}$ & $\mathbf{9 0 0 0}$ \\
\hline \multicolumn{6}{|c|}{ Table 11. Between Group } \\
Comparison of Cost of Surgery (Rs.)
\end{tabular}

't'=9.3773; $<<0.001$ (Significant)

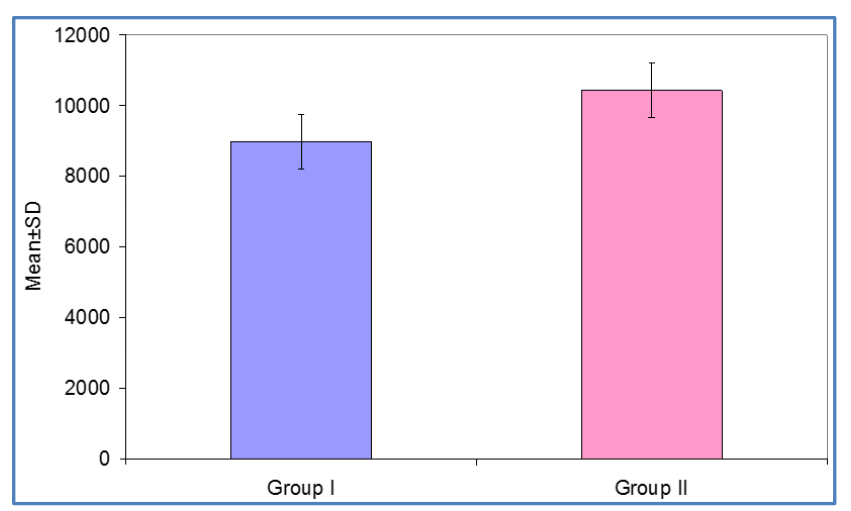

\begin{tabular}{|c|c|c|c|c|c|c|}
\hline Group & $\begin{array}{c}\text { No. of } \\
\text { Subjects }\end{array}$ & Min & Max & Mean & S.D. & Median \\
\hline Group I & 50 & 4 & 8 & 6.72 & 0.83 & 7 \\
\hline Group II & 50 & 4 & 8 & 5.52 & 1.04 & 6 \\
\hline Total & $\mathbf{1 0 0}$ & $\mathbf{4}$ & $\mathbf{8}$ & $\mathbf{6 . 1 2}$ & $\mathbf{1 . 1 1}$ & $\mathbf{6}$ \\
\hline \multicolumn{7}{|c|}{ Table 12. Between Group Comparison } \\
of Duration of Stay at Hospital (Days) \\
\hline
\end{tabular}

't'=6.384; $p<0.001$ (Significant)

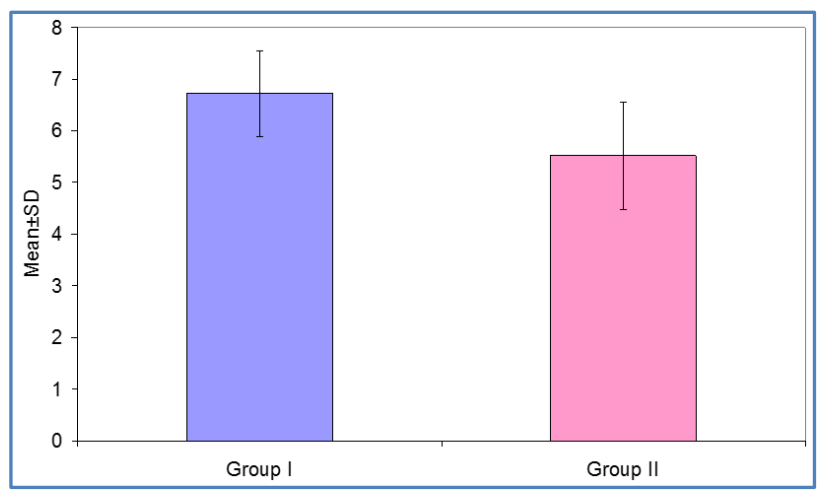

\section{DISCUSSION}

Inguinal hernias constitute an important public health problem and often pose a surgical dilemma even for the most skilled surgeon. They are the most common form of abdominal wall hernias. The incidence of inguinal hernia is unknown, but about 500,000 cases come to medical attention each year. ${ }^{20}$ In international and US surveys conducted 25 or more years ago, the prevalence of non-surgically treated inguinal hernia among men was 5-7 percent, and a similar number of men had a history of hernia repair. Inguinal hernias are painful, cause discomfort and impair the activities of life. ${ }^{21}$ There are a number of surgical techniques to perform hernia repair, viz., tension-free prosthetic repairs done through anterior approach (Lichtenstein repair, plug repair, patch and plug repair and double-layer devices) or posterior/pre-peritoneal approach (Open technique, Stoppa, Laparoscopic/endoscopic repairs) and tissue-suture repairs that include Bassini-Shouldice technique and its modifications and Marcy repair.

Today, some strong recommendations exist in favour of Lichtenstein repair. American College of Surgeons choose this technique for "gold standard", while National Institute of Clinical Excellence [NICE] from $\mathrm{UK}^{22}$ and The National Agency for Accreditation and Evaluation in Health [ANAES] from France ${ }^{23}$ recommended it for inguinal hernia repair. It is easy to learn and perform. ${ }^{24}$ However, a recent Cochrane review has shown that open pre-peritoneal mesh repair is as good as Lichtenstein procedure ${ }^{25}$ while some of the workers are of the view that open pre-peritoneal procedure not only has similar success rate but also has lesser acute and chronic pain. The Cochrane review study has also recommended randomised controlled trials for this purpose. Hence, the present study was undertaken.

In the present study, a total of 100 patients proposed to undergo hernia repair were enrolled in the study. The patients were randomly allocated to two groups- Group I had 50 patients in whom hernia repair was performed using Lichtenstein procedure whereas Group II had 50 patients in whom hernia repair was performed using Open pre- 
peritoneal mesh repair. Demographic profile, clinical presentation, risk exposures, anaesthetic needs, duration of surgery, intraoperative and post-operative complications of procedure, post-operative pain, antibiotic use, cost of procedure, duration of hospital stay, duration of resumption of activities and recurrence rates of two procedures were compared. The demographic and pre-operative clinical profile of two groups was matched.

In the present study, age of patients ranged from 17 to 85 years. Majority of patients (59\%) were above 40 years of age. Mean age of patients was $44.65 \pm 16.33$ years.

In the present study, majority of cases were male (87\%). Male to female ratio was 6.69:1. 92\% patients in Group I and $82 \%$ in Group II were males.

In the present study, majority of cases had unilateral hernia (82\%). Right side was more commonly involved (57\%) as compared to left side (25\%). Bilateral involvement was seen in $18 \%$ cases.

In the present study, history of smoking was noticed in $50 \%$ of Group I and $40 \%$ of Group II patients. Statistically, this difference was not significant $(p=0.315)$. Smoking is a known risk factor for recurrence of hernias. ${ }^{26,27}$ History of $\mathrm{BPH}$, Constipation and Cough was seen in 6\%, 9\% and 10\% cases respectively.

In the present study, no significant difference between two groups was observed with respect to side and site of swelling. Duration of swelling ranged from 2 to 12 months.

In Lichtenstein group, all the patients were operated under spinal anaesthesia (100\%). However, in open preperitoneal mesh approach, only $10 \%$ cases were operated under spinal anaesthesia, in remaining cases general anaesthesia was used.

In the present study, duration of surgery ranged from 45 to $90 \mathrm{~min}$. Mean duration of surgery was $51.60 \pm 7.03 \mathrm{~min}$. in Lichtenstein repair group as compared to $71.50 \pm 8.03$ in Open pre-peritoneal repair group, thus showing a significant difference between two groups $(\mathrm{p}<0.001)$.

In the present study, intraoperatively and immediate post-operatively, urinary retention, wound infection, haemorrhage, nerve injury and bladder injury was observed in 12, 7, 1 and 0 patients respectively in Group I and 6, 3, 7 and 1 patients respectively in Group II. A significant difference between two groups was observed for haemorrhage $(\mathrm{p}=0.012)$.

In the present study, one week post-operative pain was significantly higher in Lichtenstein group as compared to open pre-peritoneal repair group. Similar chronic pain observed at 3 months was also significantly higher in Lichtenstein group as compared to open pre-peritoneal repair group. In a recent Cochrane review, it was shown that pre-peritoneal repair causes less or comparable acute and chronic pain compared to the Lichtenstein procedure. The findings in present study showed a better response to open pre-peritoneal repair as compared to Lichtenstein repair.

In the present study, scrotal swelling, seroma formation and recurrence was seen in 4, 2 and 6 patients respectively. All the recurrences took place in Lichtenstein group only. Scrotal swelling was also seen in Lichtenstein group only. Seroma formation was seen in open pre-peritoneal repair group only. Statistically, the difference between two groups was significant with respect to recurrence and scrotal swelling.
In the present study, mean cost of procedure was Rs $8970 \pm 785$ for Lichtenstein repair and Rs $10425 \pm 766$ for Open pre-peritoneal repair. However, one must not forget that Lichtenstein repair group had 6 cases of reoccurrence $(12 \%)$, thus after adjusting for this failure rate, the actual direct cost goes up by $12 \%$ to reach at Rs $10764 /-$. In the present study, mean duration of hospital stay and resumption of work was $6.72 \pm 0.83$ and $13.92 \pm 1.31$ days respectively in Lichtenstein repair group and $5.52 \pm 1.04$ and $11.44 \pm 1.73$ days respectively in pre-peritoneal repair group.

The finding of present study suggested that postoperative complications, pain and recurrence rates were lower in pre-peritoneal repair group as compared to Lichtenstein repair group, hence open pre-peritoneal hernia repair is recommended as a surgical procedure of choice.

\section{CONCLUSION}

1. Age of patients ranged from 17 to 85 years. Majority of patients (59\%) were above 40 years of age. Mean age of patients was $44.65 \pm 16.33$ years. The age of patients in two groups was comparable.

2. Majority of cases had unilateral hernia (82\%). Right side was more commonly involved (57\%) as compared to left side (25\%). Bilateral involvement was seen in $18 \%$ cases.

3. History of smoking was noticed in $50 \%$ of Group I and $40 \%$ of Group II patients. Statistically, this difference was not significant ( $\mathrm{p}=0.315)$.

4. History of BPH, Constipation and Cough was seen in $6 \%$, $9 \%$ and 10 cases respectively. Statistically, there was no significant difference between two groups with respect to these findings.

5. Duration of surgery ranged from 45 to $90 \mathrm{~min}$. Mean duration of surgery was $51.60 \pm 7.03 \mathrm{~min}$. in Group I and $71.50 \pm 8.03$ in Group II, thus showing a significant difference between two groups $(\mathrm{p}<0.001)$.

6. Intraoperatively and immediate post-operatively, urinary retention, wound infection, haemorrhage, nerve injury and bladder injury was observed in 12, 7, 1 and 0 patients respectively in Group I and 6, 3, 7 and 1 patients respectively in Group II. A significant difference between two groups was observed for haemorrhage $(p=0.012)$.

7. One week post-operative median pain score was 7 in Group I and 6 in Group II, thus showing a significant difference between two groups $(\mathrm{p}<0.001)$.

8. At 3 months, median pain score was 3 in Group I and 2 in Group II, thus showing a significant difference between two groups $(\mathrm{p}<0.001)$.

9. Scrotal swelling, seroma formation and recurrence was seen in 4, 2 and 6 patients respectively. All the recurrences took place in Group I. Scrotal swelling was also seen in Group I only. Seroma formation was seen in Group II only. Statistically, the difference between two groups was significant with respect to recurrence and scrotal swelling.

10. Mean cost of procedure was Rs $8970 \pm 785$ in Group I and Rs $10425 \pm 766$ in Group II. Statistically, the difference was significant. However, considering the recurrence rate of $12 \%$ in Group I, the burden of average cost reaches to Rs 10764 which is comparable to that in Group II. 
11. Mean duration of hospital stay was $6.72 \pm 0.83$ days in Group I and 5.52 \pm 1.04 days in Group II. Statistically, the difference between two groups was significant.

12. Mean duration of resumption to work was $13.92 \pm 1.31$ days in Group I and $11.44 \pm 1.73$ days in Group II. Statistically, the difference between two groups was significant $(\mathrm{p}<0.001)$.

13. Considering the post-operative complications, pain and recurrence rate as the determinants of choice for selection of a surgical procedure for hernia repair, open pre-peritoneal hernia repair remains to be the surgery of choice.

\section{REFERENCES}

[1] Wexler MJ. Herniorrafia inguinal laparoscópica. In: American College of Surgeons' Scientific American Cirugía. New York: Scientific American 1995;(Suppl 5): 1-3.

[2] Lichtenstein IL. Local anaesthesia for hernioplasty. Immediate ambulation and return to work: a preliminary report. Calif Med 1964;100:106-9.

[3] Sarr MG. The tension-free hernioplasty. Am J Surg 1990;160(1):139-41.

[4] Heikkinen TJ, Haukipuro K, Hulkko A. A cost and outcome comparison between laparoscopic and Lichtenstein hernia operations in a day-case unit. A randomized prospective study. Surg Endosc 1998;12(10):1199-203.

[5] Cheek CM, Black NA, Devlin HB, et al. Groin hernia surgery: a systematic review. Ann R Coll Surg Engl 1998;80(Suppl 1):S1-80.

[6] Rutkow IM. Demographic and socioeconomic aspects of hernia repair in the United States in 2003. Surg Clin North Am 2003;83(5):1045-51.

[7] Sajid MS, Craciunas L, Singh KK, et al. Open transinguinal pre-peritoneal mesh repair of inguinal hernia: a targeted systematic review and metaanalysis of published randomized controlled trials. Gastroenterology Report (Oxf) 2013;1(2):127-37.

[8] Amid PK. Lichtenstein tension-free hernioplasty: its inception, evolution and principles. Hernia 2004;8(1): 1-7.

[9] MacFadyen BV, Mathis CR. Inguinal herniorrhaphy: complications and recurrences. Semin Laparosc Surg 1994;1(2):128-40.

[10] Lepere M, Benchetrit S, Debaert M, et al. A multicentric comparison of transabdominal versus totally extraperitoneal laparoscopic hernia repair using PARIETEX meshes. J Soc Laparoendosc Surg 2000;4(2):147-53.

[11] McCormack K, Scott NW, Go PM, et al. Laparoscopic techniques versus open techniques for inguinal hernia repair. Cochrane Database Syst Rev 2003;1:CD001785.

[12] Heikkinen T, Bringman S, Ohtonen P, et al. Five-year outcome of laparoscopic and Lichtenstein hernioplasties. Surg Endosc 2004;18(3):518-22.
[13] Olmi S, Erba L, Magnone S, et al. Prospective study of laparoscopic treatment of incisional hernia by means of the use of composite mesh: indications, complications, mesh fixation materials and results. (In Italian). Chir Ital 2005;57(6):709-16.

[14] Rehman QU, Shah TA Latif U. Inguinal hernia: Lichtenstein and Darn repair: a comparative study. Prof Med J 2010;17(1):50-4.

[15] Legutko J, Pach R, Solecki R, et al. The history of treatment of groin hernia. Folia Med Cracov 2008;49(1-2):57-74.

[16] Notash YA, Notash YA Jr, Farshi SJ, et al. Outcomes of the Rives-Stoppa technique in incisional hernia repair: Ten years of experience. Hernia 2007;11(1):25-9.

[17] Deysine M. Recurrent inguinal herniorrhaphy. A centripetal approach utilizing a preformed polypropylene plug. Hernia 2008;12(3):271-5.

[18] McCormack K, Wake B, Perez J, et al. Laparoscopic surgery for inguinal hernia repair: systematic review of effectiveness and economic evaluation. Health Technol Assess 2005;9(14):1-203.

[19] Bhandarkar DS, Shankar M, Udwadia TE. Laparoscopic surgery for inguinal hernia: current status and controversies. Journal of Minimal Access Surg 2006;2(3):178-86.

[20] Everhart JE. Abdominal wall hernia. In: Everhart JE, edr. Digestive diseases in the United States: epidemiology and impact. Bethesda, MD: National Institute of Diabetes and Digestive and Kidney Diseases 1994:471-507.

[21] Jenkins JT, O'Dwyer PJ. Inguinal hernias. BMJ 2008;336(7638):269-72.

[22] National Institute of Clinical Excellence (NICE) Final appraisal determination, laparoscopic surgery for inguinal hernia repair. London, 2004.

[23] The National Agency for Accreditation and Evaluation in Health (ANAES) Clinical and economic evaluation of laparoscopic surgery in the context of inguinal hernia repair. Paris, 2000.

[24] Paajanen H, Varjo R. Ten-year audit of Lichtenstein hernioplasty under local anaesthesia performed by surgical residents. BMC Surg 2010;10:24.

[25] Willaert W, De Bacquer D, Rogiers X, et al. Open preperitoneal techniques versus Lichtenstein repair for elective inguinal hernias. Cochrane Database of Systematic Reviews 2012;(7):CD008034.

[26] Sorensen LT, Friis E, Jorgensen T, et al. Smoking is a risk factor for recurrence of groin hernia. World J Surg 2002;26(4):397-400.

[27] Jansen PL, Klinge U, Jansen M, et al. Risk factors for early recurrence after inguinal hernia repair. BMC Surgery 2009;9:18. 